\title{
Students' attitudes towards blended language courses: A case study
}

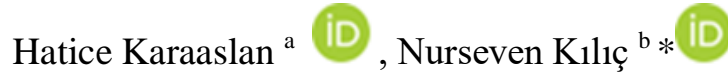 \\ ${ }^{a}$ Ankara Ylldrrm Beyazıt University, Ankara 06010, Turkey \\ ${ }^{b}$ Ankara Ylldırlm Beyazit University, Ankara 06010, Turkey
}

APA Citation:

Karaaslan, H., \& Kılıç, N. (2019). Students' Attitudes towards Blended Language Courses: A Case Study. Journal of Language and Linguistic Studies, 15(1), 174-199.

Submission Date: 07/28/2018

Acceptance Date: 01/26/2019

\begin{abstract}
In an effort to create enriched language learning environments, language teachers, program and course developers, and publishing companies have long sought novel ideas and alternatives. Thus, a wide range of information and communications technologies, which have manifested themselves in the form of virtual learning environments, web-based platforms, or mobile-assisted applications, have been embraced in the field. With the introduction of new means and platforms for delivering instruction outside the classroom, blended learning, combining e-learning and conventional classroom methods as well as providing room for student control over the learning process, has gained popularity as a promising option. In this case study, which focuses on a group of second-year English language students at a School of Foreign Languages, the goal was to investigate students' attitudes towards blended learning with reference to six learning aspects: learning-flexibility, online-learning, study-management, technology-use, classroom-learning, and online-interaction (Tang \& Chaw, 2013). Students' responses to the attitude questionnaire were subjected to descriptive statistical analysis as well as internal consistency tests among subscales. A subsequent focus group meeting was held with a group of 15 students to attain qualitative data on their views and attitudes towards blended learning with respect to their experiences and expectations. Highachievers had a tendency to hold positive attitudes towards all learning aspects while low-achievers required more face-to-face in-class time, interaction and study management support, pointing to possible links among such variables as language proficiency, learner autonomy and attitudes towards blended learning and highlighting how critical student characteristics and attitudes could prove in the implementation process.
\end{abstract}

C 2019 JLLS and the Authors - Published by JLLS.

Keywords: Blended learning; student attitudes; autonomy; language proficiency; learning adaptability

\section{Introduction}

Using technology in education, especially its integration in language teaching and learning, is not a new concept, dating back to Computer-Assisted Language Learning (CALL) in the 1960s (Levy, 1997). Those were the times when teaching or learning through computers was an effortful activity as the resources were scarce and costly, and many students and teachers were dissatisfied by the lack of success in making such services accessible to all involved (Beatty, 2010). However, with the increase in technological developments and their widespread use, accompanied by a drop in prices, in the late 1970s and 1980s, computers for educational use in general and language teaching purposes specifically could

\footnotetext{
${ }^{*}$ Corresponding author. Tel.: +9-506-836-7845

E-mail address: nkilic@ybu.edu.tr
} 
become more widely available (Levy, 1997). Over time, especially upon the emergence of the World Wide Web and the Internet, CALL content has transformed significantly, from those initial simplistic and relatively more behavioristic textbook style gap-filling tasks to interactive and integrative multimedia activities that rely on the sound, animation and full-motion video options available in today's virtual environments and encourage learners to take on the responsibility for their own learning and become more independent (Karatay, 2016; Chapelle, 2001; Chapelle, 2010).

\subsection{Virtual learning environments and blended learning}

In an effort to create enriched language learning environments, language teachers, program and course developers, and publishing companies have long sought novel ideas and alternatives. Thus, a wide range of information and communications technologies, manifesting themselves in the form of virtual learning environments, web-based platforms, or mobile-assisted applications in which learners and teachers can view and interact with the content any time anywhere (Saran, Seferoğlu \& Çağıltay, 2012), have been embraced in the field. The Internet, providing the main medium for delivering content in an interactive manner, has benefitted individual teachers and students around the world, as well as large publishing companies in significant ways, and today, CALL applications including email, chat, blog, social networking sites, corpus, e-books, or online labs among others take language teaching and learning to a whole new level for their audience.

With the introduction of such means and platforms for delivering instruction outside the classroom, blended learning, combining e-learning and conventional classroom methods as well as providing room for student control over the learning process, has gained popularity as a promising option. As illustrated in Figure 1 below, providing multimodal practice with feedback, addressing individuals' needs and goals in a crowded class, offering variety in resources and real life skill-building in computer use, including motivational fun elements, and allowing collaboration among peers as well as self-reflection and learner autonomy are among the many benefits of complementing traditional classroom teaching with elearning (Tang \& Chaw 2013; Karatay, 2016).

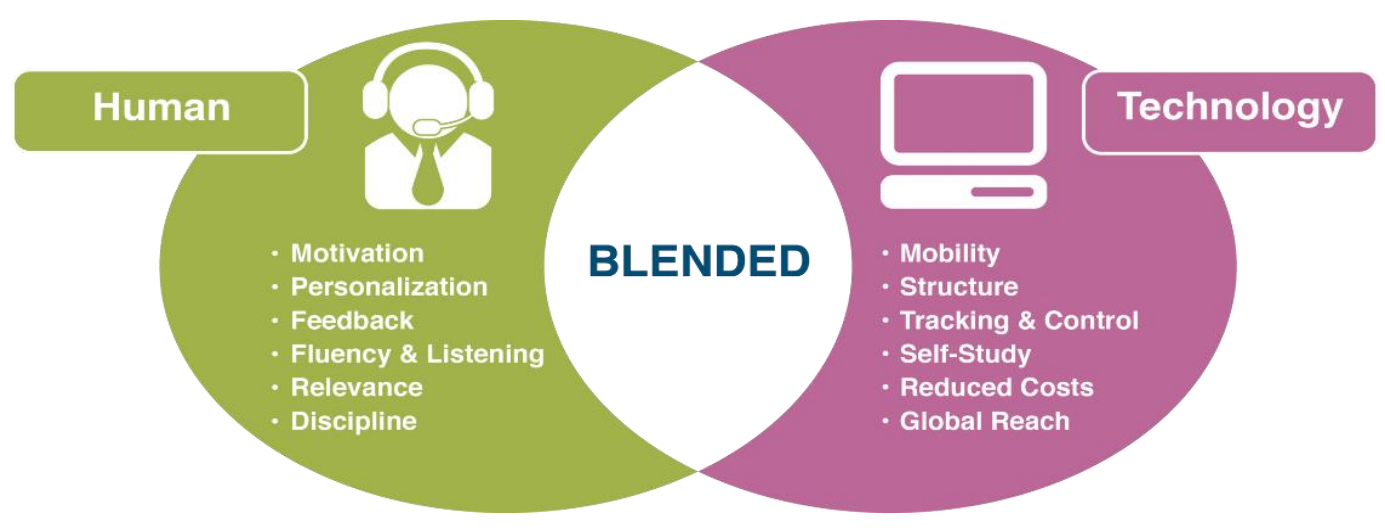

Figure 1. Elements of blended learning (Source: https://tinyurl.com/ydecxyzp)

Hence, both instructors and students have positive attitudes towards the incorporation of such technology and content and they value the experience with such media (Ayres, 2002; Warschauer and Kern, 2000; Rico \& Vinagre, 2000; Sadeghi \& Dousti, 2012; Chun \& Plass, 1997; Arikan, 2009; Shin \& Son, 2007 as cited in Karatay, 2016; Chapelle, 2009; Lopez-Perez et al., 2011 as cited in Tang \& Chaw, 2013; Yelbay, 2011). Electronic content and services have been reported to be of use with listening, reading, writing, speaking, vocabulary, grammar and spelling practice along with providing 
the opportunity to collaborate with others globally through email or conferencing facilities, considering the student population. For the content developers or teachers, e-learning is found to be a resourceeffective methodology providing them with the tools (authoring packages, digital data or media, dictionaries, concordancers, translation, transcription or screencast tools) and constantly updated materials (Karatay, 2016). Students are allowed space and flexibility as to what, where, and how to study and their autonomous learning process is facilitated through synchronous and asynchronous options, content appealing to various learning styles and intelligences, immediate feedback and classroom applications (Rahman, Hussein \& Aluwi, 2015).

Despite these advantages of integrating technology in education, there are also some issues relating to security, ethics, computer literacy or digital wisdom (Wang \& Heffernan, 2010; Chen, 2008; Koehler \& Mishra, 2009; Prensky, 2001 as cited in Karatay, 2016). The integration of technology in educational settings requires both teachers and students to take on new roles (Bañados, 2006 as cited in Karatay, 2016), and thus they need to be informed and trained on the process adequately in order to make use of e-learning or blended learning in the best way possible. In the absence of such training or orientation for teachers and students or the essential technical infrastructure, participants might suffer potential drawbacks from inadequate internet connectivity, lack of technical support, slow updates or enhancements on the online platform to lack of well-trained teachers or students with limited or no orientation (Dudeney \& Hockly, 2007).

In this respect, to support the teaching process and enhance the learning experience, blended learning needs to go beyond a mere replication of the traditional classroom instruction. As a medium of instruction, the e-learning component in blended learning is achieved through coverage of content before class time (i.e. instructional videos, recorded lectures and online digital instructional materials) so that instructors allocate more class time to complex problem solving, deeper conceptual coverage and peer interaction. It should further contribute to the teaching-learning process in terms of allowing personalized learning (e.g., learner needs, pace), variety, and student preparation in advance, increasing student participation and interaction, and overcoming time-related limitations (Basal, 2015; Çelebi, Karaaslan \& Demir, 2016; Korkmaz \& Demir-Başaran, 2016; Shannon-Chastain \& Fell-Kurban, 2016).

\subsection{Developing a customized blended learning course: managing the change}

Considering the potential problems that might result from any untimely or premature implementation of blended learning procedures, institutions planning to incorporate e-learning options more widely need to adopt a gradual transition period and run studies into the perspectives of all the parties involved, including program designers, content developers, teachers/instructors, and students most importantly. Once its students feel confident about and ready for pursuing their language learning studies in a blended learning environment, the institution can seriously consider implementing the blended approach and plan the stages of this shift in an efficient way.

Any planning of such transformation requires starting small and managing the change process systematically following a framework of leading change with a consideration of the institutional needs and expectations. In our specific context, at Ankara Yildırım Beyazit University School of Foreign Languages (AYBU-SFL), one such model by Kotter (2012), in Figure 2 below, involving the phases of creating a climate for change, engaging and enabling the whole organization, and implementing and sustaining change, was adopted to manage the process: 


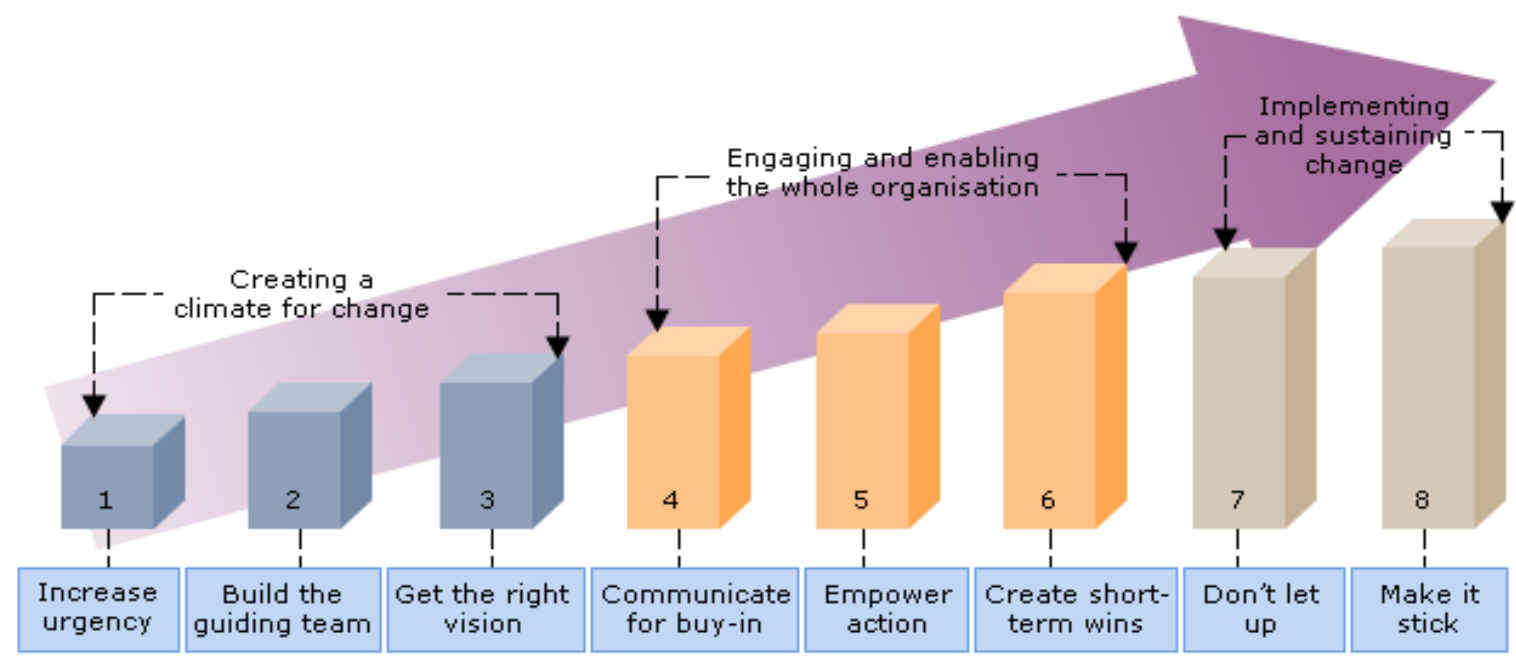

Figure 2. Leading change by Kotter (2012)

At AYBU-SFL, as in many other English preparatory schools in Turkey, students are exposed to an intensive foreign language training program, English in this case, over a period of one year before they start their departmental program, and there is a huge demand for language presentation and practice materials not only for classroom use but also for self-study purposes outside the school. In an effort to meet students' needs for extra practice and reference materials, many online language training platforms have become commercially available for preparatory schools' use. Subsequently, decision-makers and program developers at such institutions have started gradually integrating electronic or online content to suit the convenience of their students, teachers, and program demands, selecting from a range of options including a $100 \%$ online course, typically known as distance education; a $75 \%$ online and $25 \%$ face-to-face course; and finally a $100 \%$ face-to-face course with supplementary online content, a widely employed blended learning approach in many language teaching contexts (Dudeney \& Hockly, 2007), as there is no one-fits-all approach in blending learning.

In this naturally emerging climate of change or transformation resulting from the demands of today's language teaching environments, at its initial stages at AYBU-SFL, blended learning began in the form of a $100 \%$ face-to-face instruction supplemented with online content for homework, revision and practice materials. That is why, the change found immediate acceptance in the school as it extensively met program demands under the supervision of the guiding team that worked in collaboration with all the parties involved to get across the right vision. Despite such effort, there were occasional complaints as to certain features of the different online platforms utilized considering the costs involved and it took time to engage and enable the whole organization, and subsequently implement and sustain the change. Even today, after more than six years of implementing the blended approach in the form described, the school keeps updating its policies for electronic content use based on feedback from all stakeholders in an effort to enhance its sustainability.

Building on this blended program experience with the general English preparatory school student population, as of the 2015-2016 academic year, AYBU-SFL initiated a substantially different version of the blended learning program to be used with its so-called 'repeat' students who could not attain the pass score in the English proficiency exam at the end of their first year of study and were required to study at the English preparatory school in their second year (for one or two terms) again. Prior to this policy change, the institution did not offer any alternative program to such students and they used to be enrolled in the same classes with the new enrolment groups. As such, they posed a challenge in that teachers and coordinators had difficulty in identifying and catering for their individual needs ranging 
from personal, familial issues to general difficulties in language learning such as not knowing where to start, trying many times but not finding the right way, being worried if what they are doing is right, not improving their test scores despite trying hard, feeling alone when studying or not being able to manage their study time efficiently. Without an individual-specific attention that would scaffold their learning process with a consideration of how each would be able to develop his route to linguistic and academic success, they kept failing across most levels, ended up suffering for more than a year, and eventually dropped out. Therefore, with the policy change, in their second year, these students were offered a blended learning program providing them with 8-hour face-to-face instruction on productive skills and 15-hour online practice on receptive skills on a weekly basis.

The rationale for this format and content was two-fold: to provide some flexibility in their schedules for their individual needs and to ensure detailed feedback on their performance, which could be enhanced in a collective learning environment. In the first year of its implementation, the program was offered only as an alternative and only those who volunteered to join attended it. However, at the end of that academic year, having observed its benefits compared to the existing program and better student performance, the school administration decided to introduce a policy change and make this alternative blended program compulsory for all the second-year English preparatory school students, and the program, with some updates and modifications following the cycle in Kotter's (2012) model of leading and sustaining change, has been in use for two more academic years now (Please see Appendix A for a sample blended B+ level syllabus which includes information on the weekly learning outcomes, course materials, in-class and online content, portfolio tasks, online tasks and assignments, weekly word lists, reference materials for reading and listening practice, evaluation criteria and contact people.)

As part of the efforts to enhance the sustainability of the compulsory blended learning program for the repeat students at AYBU-SFL and to ensure the efficient operation of the system as a whole, certain measures were taken prior to its implementation. A platform, not requiring a high-speed Internet connection, was preferred, and its content would be regularly updated and improved. Teachers and students would be provided with the necessary orientation at the beginning of the year and regularly throughout the year, and well-trained technical staff would be available for guidance and training upon request. Student learning would be facilitated with having multiple attempts at online exercises, getting immediate feedback, and studying at their own pace, following the best practices in the related literature (Sagarra \& Zapata, 2008; Harker \& Koutsantoni, 2005).

Consequently, and as part of the sustainability of change purposes again, this study focuses on a group of second-year English preparatory school students at AYBU-SFL and aims to investigate students' attitudes towards blended learning, as illustrated and experienced in this compulsory blended program, with reference to the six learning aspects identified by Tang and Chaw (2013), including learning flexibility, online learning, study management, technology, classroom learning, and online interaction, over two academic years.

\subsection{Research questions}

In the direction of the above discussion, the current study attempts to answer the following research questions:

1. What are students' attitudes towards blended learning with respect to the six learning aspects of learning flexibility, online learning, study management, technology, classroom learning, and online interaction?

2. What are students' views and attitudes towards blended learning with respect to their experiences and expectations? 


\section{Method}

\subsection{Context of the study and participants}

The current study was conducted in the School of Foreign languages at an English-medium state university in the 2016-17 and 2017-18 academic years. In the regular English preparatory program, students are enrolled in different levels on the basis of their initial language scores obtained from the placement exam and they follow the syllabi appropriate for their levels. On condition that they fulfill the requirements of school regulations related to exams, they have the proficiency exam (called AGE, Assessment of General English) at the end of each academic year. If students cannot get the required pass score, they are supposed to repeat the English preparatory program again. In the second year, these learners attend the lessons in a blended learning program giving them the opportunity to reach online resources to practice reading and listening and 8-hour tutorials each week on speaking and writing. Students are offered this course design and content so as to provide some flexibility in schedules and to enable them to receive detailed, face-to-face feedback on their performance. The blended learning, specifically designed for this group of learners, may be a handy, smooth, and student-friendly approach to include learners in the learning process by presenting them several advantages like embedding faceto-face interaction in flexible schedules. Within this scope, students' attitudes towards the six learning aspects (learning flexibility, online learning, study management, technology, classroom learning, and online interaction) are explored in this study. For that purpose, 281 second year preparatory school students with the levels of pre-intermediate $(\mathrm{N}=30)$, intermediate $(\mathrm{N}=91)$ and upper-intermediate $(\mathrm{N}=160)$ participated in this study.

\subsection{Instruments}

Data regarding students' attitudes towards blended learning were collected through a 5-point Likerttype questionnaire and a focus group meeting. The questionnaire administered was modified from Tang and Chaw (2013), comprising six constructs and 34 items in total. The six constructs were learning flexibility, online learning, study management, technology, online interaction, and classroom learning. All the items of individual constructs were kept the same except the last part including three items for intention, willingness and planning to join in a blended learning program as the participants are already blended learners. The questionnaire includes the items such as "I like to study on my own pace" for learning flexibility; "I find it very difficult to study online" for online learning; "I organize my time better when studying online" for study management; "I find Web technologies easy to use" for technology; "I would like to interact with my lecturer online" for online interaction; and "I learn better when someone guides me personally" for classroom learning. In the current study, the internal consistencies of the subscales (Cronbach's coefficient alpha) were .70 for Learning Flexibility (LF), .77 for Online Learning (OL), .83 for Study Management (SM), .77 for Technology (TE), .67 for Online Interaction (OI), and .75 for Classroom Learning (CL). Also, the alpha reliability coefficient of the entire questionnaire was found as .84 . As can be observed, the findings in our sample revealed satisfactory internal consistencies for all subscales.

Following the administration of the attitude questionnaire, students were asked to participate in a 50minute focus group meeting, discussing their views and attitudes on the constructs of learning flexibility, online learning, study management, technology, online interaction, and classroom learning as described in the attitude questionnaire and experienced during their studies at the school. 


\subsection{Data collection and analysis}

Prior to the study, all the ethical procedures of the study were completed and the study was approved by the Ethics Committee of Ankara Y1ldırım Beyazıt University. The participants contributed to the study with their informed-consent. The questionnaire was administered at the end of the fall terms of 2016-2017 and 2017-2018 academic years and students were asked to rate each item on the questionnaire, ranging from 1 :strongly disagree to 5:strongly agree, in 15 minutes during their classes. The questionnaire data were entered into a Statistical Package for the Social Sciences (SPSS) 22 program for descriptive statistical analysis; and means, standard deviations and percentages were reported in the table and figures.

Subsequently, a 50-minute focus group meeting was conducted with a group of 15 students who volunteered to participate in the task and presented their views and attitudes regarding the blended learning aspects as experienced during their studies at the school. The entire meeting was recorded on a cell phone, and 50 minutes of spoken data was collected and transcribed by the researchers. 15 students participated in the focus group meeting. The content analysis (Creswell, 2012) was carried out as follows: (1) organize the data, (2) explore and code the data, (3) construct descriptions and themes, (4) identify the qualitative findings, (5) interpret the findings, and (6) validate the accuracy of the findings. During the data analysis, the transcribed spoken data were read individually and grouped based on the points students considered, including learning flexibility, online learning, study management, technology, online interaction, and classroom learning. At the same time, the researchers analyzed and generated questions in order to determine further common themes or patterns. Both researchers compared and discussed the content analysis to finalize the themes. The explanations were aligned with these findings. The findings were presented without comment to demonstrate the actual data, and then the results were interpreted.

\section{Results}

\subsection{Students' attitudes towards blended learning and related constructs}

The means and standard deviations of the students' ratings in response to the questionnaire items related to constructs that involve learning flexibility, online learning, study management, technology, classroom learning, and online interaction are reported in Table 1 below for all participants of the study, covering both 2016-2017 and 2017-2018 academic years. Prior to the analysis for descriptive statistics in SPSS, the negative items $(5,11,12,13,28)$ were reverse coded. Findings indicated that the students had positive attitudes towards the six learning aspects of blended learning in most respects.

Table 1. Means and standard deviations of the questionnaire for all participants

\begin{tabular}{lccccc}
\hline & T* & M & SD & N & \% \\
\hline LF & 20 & 17.37 & 2.70 & 281 & 86.8 \\
OL & 40 & 19.38 & 5.90 & 281 & 48.4 \\
SM & 30 & 15.27 & 5.46 & 281 & 51 \\
TE & 20 & 14.59 & 3.35 & 281 & 72.9 \\
CL & 25 & 21.01 & 3.30 & 281 & 84 \\
OI & 35 & 24.35 & 4.75 & 281 & 69.6 \\
Total & 170 & 111.97 & 25.46 & 281 & \\
\hline
\end{tabular}


LF: Learning Flexibility; OL: Online Learning, SM: Study Management; TE: Technology; CL: Classroom Learning; OI: Online Interaction. $\mathrm{T}^{*}$ represents the highest mean score possible; e.g., for the Learning Flexibility subscale, it is 5 (the highest point on the scale); $* 4$ (number of items in this subscale) $=20$.

In order to be able to compare student ratings across subscales with varying numbers of items, the relevant percentages (the "\%" column in Table 1, above) were calculated using the totals (the highest mean possible in each case) and the actual mean values of the data collected. Based on these percentages, it was revealed that the Learning Flexibility subscale, which included items such as "I would like unlimited access to lecture materials", received the highest ratings from the students $(87 \%)$. The subscales of Classroom Learning, Technology, and Online Interaction received the second highest set of ratings (84\%, 73\%, and 69\% respectively) while the Study Management (51\%) and Online Learning (standing close to $48 \%$ ) subscales received relatively lower ratings.

In order to determine the specific items that were rated relatively negatively and thus needed further attention, the students' ratings for each item under each subscale were examined more closely. Therefore, the individual means of all items in the survey were computed and compared against the mean of the subscale each belongs to. Accordingly, the items that were around or below their respective subscale means were selected and enlisted as high-priority items to be investigated further. These items were "I would like to have my classes online rather than in the classroom", "I would like lecture time in the classroom to be reduced", "I like online learning as it provides richer instructional content" and "I do not resist having my lessons online" for the Online Learning subscale. Maximum rating to be given for all the items is 5 and these items received the mean score of 1.95, 2.18, 2,61 and 2.66 respectively. Similarly, for the Study Management subscale, the four items "Online Learning encourages me to make plans", "Online learning motivates me to prepare well for my studies", I organize my time better when studying online" and "I can study over and over again online" received the following mean scores respectively: $2.37,2.41,2,52$ and 2.60 .

The means of the students' ratings of the questionnaire are also shown in Figure 1 below to illustrate their general tendency regarding the six aspects of blended learning across two academic years' with a consideration of their English language levels.

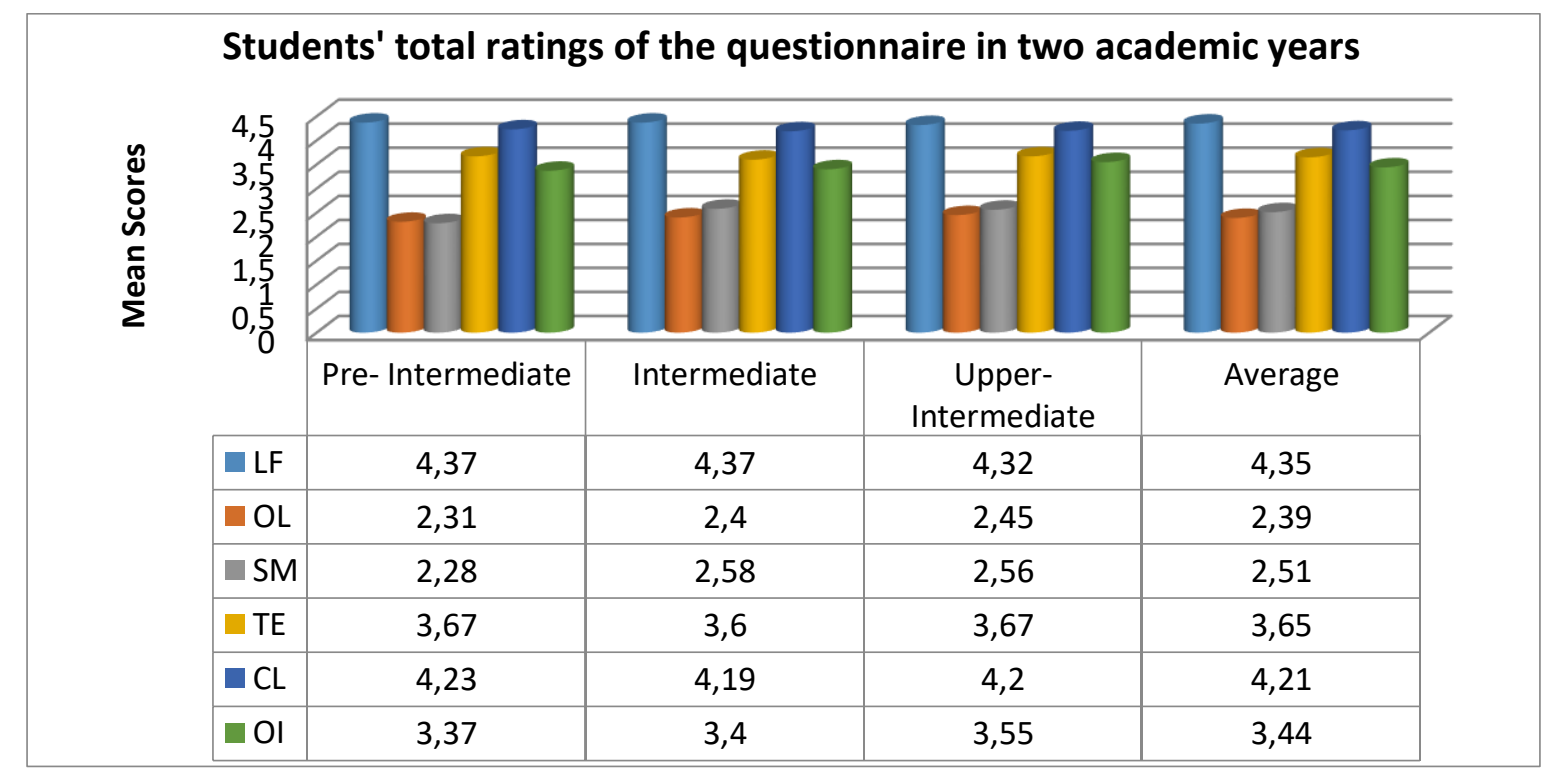

Figure 1. Means of the students' ratings for the blended learning aspects across the 2016-2017 and 2017-2018 academic years with respect to their English language levels. 
As illustrated in Figure 1, the overall mean score gathered from the entire questionnaire was around 3,43 . The Learning Flexibility subscale received the highest mean score of 4,35 , standing out as the most favorable blended learning aspect from the students' perspective. It entails that students are pleased with being able to access and use learning materials when needed at their own pace. The Classroom Learning subscale received the second highest mean score of 4,21, pointing to the importance of affective factors in that the need and desire for face-to-face interaction cannot be underestimated in learning settings even if the benefits of blended learning are huge. The subscales of Technology and Online Interaction had the following set of mean scores, 3,65 and 3,44; while the Study Management and Online Learning subscales stood in the lowest band with mean scores of 2,51 and 2,39 respectively. As figure 1 above presents, set of ratings for any subscales do not vary by English level of students across two academic years. Ratings are spread over each construct smoothly and the attitudes of the students in all levels seem homogenous in the general assessment of the scores of two academic years.

To be more specific, the means of the students' ratings of the questionnaire are shown in Figure 2 to explore the potential similarities or differences in their ratings for the 2016-2017 academic year individually. The sets of ratings of this year are illustrated in Figure 2 as follows:

\begin{tabular}{|c|c|c|c|c|}
\hline \multicolumn{8}{|c|}{ Students' ratings of the questionnaire in 2016-2017 academic year } \\
\hline
\end{tabular}

Figure 2. Means of the students' ratings for the blended learning aspects in the 2016-2017 academic year with respect to their English language levels

As Figure 2 above indicates, regarding the distribution of percentages, the Learning Flexibility subscale received the highest ratings from the students $(89,8 \%)$. The subscales of Classroom Learning, Technology and Online Interaction received the second highest set of ratings $(84,4 \%, 71,6 \%$, and $71,2 \%$ respectively) while the Study Management and Online Learning subscales received relatively lower ratings with $48,4 \%$ and $46,6 \%$. A closer examination of their corresponding mean scores reveals that the Learning Flexibility subscale received the highest ratings from the students with a general mean score of 4,49. In all language levels, students are in favour of the Learning Flexibility subscale. However, the case differs in other subscales. For instance, some subscales like the Online Learning and Study Management had relatively lower mean scores in pre-intermediate $(1,9$ and 1,89) and intermediate groups ( 2 for both), while the set of mean scores of these subscales were 3,2 and 3,26 in the upperintermediate group. In addition, for the Technology subscale, approximately one mean score difference 
was observed between the mean scores of upper-intermediate group $(4,24)$ and the other two groups $(3,25)$. Similarly, the ratings for the Online Interaction subscale produced a higher mean score $(4,08)$ in the upper-intermediate group in comparison to the mean scores of pre-intermediate $(3,3)$ and intermediate $(3,3)$ groups. Further, the mean score was 4,54 in pre-intermediate and intermediate groups for the Classroom Learning subscale while it was computed to be 3,58 in the upper-intermediate group, standing close to one mean score difference. On the whole, excluding the Learning Flexibility subscale with similar mean scores across the three language levels, the subscales of Online Learning, Study Management, Technology and Online Interaction received relatively higher ratings from the upperintermediate group while the subscale of Classroom Learning received lower rating from the upperintermediate group, pointing to the variance that exists across the groups based on their English language levels that might have some relevance to their independent study behaviour as required in online learning environments.

Following the same line of argument as to whether there exists any variance in students' ratings for the blended learning aspects based on their language levels during the 2017-2018 academic year, the means of their ratings of the questionnaire are reported in Figure 3 as follows:

\begin{tabular}{|c|c|c|c|c|}
\hline \multicolumn{8}{|c|}{ Students' ratings of the questionnaire in 2017-2018 academic year } \\
\hline
\end{tabular}

Figure 3. Means of the students' ratings for the blended learning aspects in the 2017-2018 academic year with respect to their English language levels

As shown in Figure 3 above, considering the distribution of percentages, the Learning Flexibility subscale got the highest ratings from the students (85\%). The Classroom Learning, Technology, and Online Interaction subscales received the second highest ratings $(83,2 \%, 74 \%$ and $70 \%$ respectively) while the Study Management and Online Learning subscales had relatively lower percentages, standing close to 52,4\% and 49,8\%. The spread of percentages in the 2017-2018 academic year revealed a similar pattern to that in the 2016-2017 academic year. On the other hand, the variance that existed in students' subscale ratings due to their language levels was not observed in the data gathered in the 2017-2018 academic year. The Learning Flexibility subscale had the highest mean score of 4,25, and the Classroom Learning subscale had the second highest mean score of 4,16 , neither varying significantly across the groups. A relatively lower set of mean scores were computed for the Technology $(3,7)$ and Online 
Interaction $(3,5)$ subscales, while the Study Management and Online Learning subscales had the lowest mean scores of 2,62 and 2,49 respectively, again none varying significantly across the groups.

In sum, when the data from both academic years were collapsed and analysed, the language-level based variance observed in the 2016-2017 academic year disappeared in the entire data set. A closer examination of the overall respective subscale means and percentages revealed that the students had positive attitudes regarding the six blended learning aspects though with some variance in amount such that their attitude ratings for the Learning Flexibility and Classroom Learning subscales were relatively high, as opposed to the moderate ratings for the Technology and Online Interaction subscales, and quite low attitude ratings for the Study Management and Online Learning subscales.

\subsection{Students' views and attitudes towards blended learning with reference to their experiences and expectations}

The students were asked to reflect on their experiences and expectations in relation to blended learning and its related constructs including learning flexibility, online learning, study management, technology, online interaction, and classroom learning for the purposes of this study in a focus group discussion session. They had positive views and attitudes towards blended learning in most respects though they pointed out some of its drawbacks and offered some ideas for improvement.

With respect to Learning Flexibility (LF), which entails that learning resources are available for access anytime anywhere, students held positive view and attitudes in general and they enjoyed not being stressed due to physical constraints. On the other hand, they also reported that such flexibility led to acts of procrastination in some in that knowing that one could have access to study materials 7/24 resulted in time management issues. Some admitted that they kept delaying their studies until the very last minute, asked for deadline extensions, and eventually tried copying answers from their classmates in an effort to catch up with the work as they had to complete the online assignments and tasks within a specified period of time to attain the necessary points and get a pass score in the end. Consequently, they said they ended up forgetting what they already knew in the absence of regular study, especially suffering from poorer writing and speaking performance. In relation to the second construct, Online Learning (OL), and following from the problem reported here, some also thought although they were aware that the online resources were useful and would help them improve as language learners gradually if they worked on them in a systematic way, they were occasionally stressed under this scoring aspect of their completed assignments and thus could not benefit from the resources efficiently. Further, some students said they were not ready for using online resources as well as not viewing online materials as decent exercises for language development (as they wanted to work on exam practice materials that were exactly like the ones in the proficiency exam); therefore, they preferred print study materials instead or did not take the online resources seriously. On the whole, though, all admitted that these issues were rooted in their problems regarding Study Management (SM), which corresponds to the third construct of blended learning. Despite the problems they had adapting to the online learning environment, they were convinced that they were not equipped with the essential study management skills that required taking the responsibility of their own learning and being able to cope in a learning context where both flexibility and discipline were facilitated at the same time. Otherwise, nobody reported any difficulty using online platforms with respect to the construct of Technology ( $T$ ) as they claimed in this technology age they all knew how to use technology and communication tools while exchanging ideas or documents and spreading information among themselves.

Another point that emerged as a significant issue in the focus group discussion was with respect to the Classroom Learning (CL) construct. In a blended environment, CL is quite limited with respect to time and/or scope; that is, face-to-face time is confined to certain higher order skills generally, which require teacher facilitation of the learning process, while most tasks of relatively repetitive nature are 
reserved for outside-the-school online or independent study. Some students raised the issue of limited face-to-face or Classroom Learning (eight hours weekly), specifically complaining about how hard it was to get motivated and encouraged to work on a systematic basis in the absence of regular and frequent face-to-face meetings which could help them build better rapport among themselves and with teachers. Again, relating this back to SM, some highlighted the importance of getting peer support or teacher support while planning and organizing their studies over a long period of time, for like three or four months, and the positive influence of being checked or monitored by some sort of a mentor, either a teacher or a more motivated/disciplined classmate, reminding them of their goals, motives, and accomplishments. In this respect, such relatively lower achieving students thought longer face-to-face time regarding $\mathrm{CL}$ would be beneficial, to stay focused with respect to SM. Thus, in their definition, SM is closely related with getting motivated, setting goals, planning and organizing their studies and time, and completing their tasks, all of which could be achieved in the presence of mentors, namely in a collaborative learning environment. However, what some referred to was not necessarily physical contact or something in the form of longer face-to-face classes, but close interaction with peers and teachers, which might as well refer to the Online Interaction (OI) aspect of blended learning.

With respect to OI, they were content with the kind of content-related support they received from their teachers; however, some sought more individual-specific attention regarding motivational aspects as they did not want to study English any more out of boredom or repeated failure or had expectations such as being checked or monitored by their teachers more closely. Such students expected their tasks or progress to be tracked on a more frequent basis, and they complained about not being able to benefit from study groups. In blended learning classes, students had online class memberships through freely available online networking platforms (e.g. Edmodo, remind, google groups, etc.) and they had material and forum exchanges there. Besides, they were advised to form smaller study groups (three or four students together) based on their WINs (wants, interests, needs) or strengths and weaknesses, and work together towards shared goals on a voluntary basis. However, as reported during the focus group discussion, some students found it difficult to get in such study groups or benefit from OI options. They said hard-working or disciplined students would prefer students of similar nature while forming groups and they would remain with the ones who would have study management issues like themselves; thus, even if they joined some study groups, they would end up wasting most of their time with long hours of inefficient study strategies or dealing with interests other than improving their English such as finding a part-time job, traveling, socializing or playing online games. With fewer in-class hours, some reported that they had more flexibility in their schedules, but they could not use it in an efficient way as they were not used to studying in the absence of an authority figure who dictated them what/when/where/how to study. They said they had difficulty staying focused, finding structure in what they were doing, and spent hours feeling regretful for the time wasted. These were all stated as drawbacks of the interaction offered in an online, blended environment that build around the constructs of LF, SM, and CL, as opposed to the advantages of utilizing online resources including LF, OL, T, and OI.

Other issues that were brought up during the focus group discussion, did not directly fall into any of the constructs above but proved considerably important for the critical considerations of this study, were about teachers' attitude towards students and the cost of online resources. Students all agreed that, in blended classes as students with relatively lower levels of motivation and poorer performance in their second-year at the school, they were glad with how positively and constructively their teachers approached and treated them, but criticized some of their teachers in their first year in this respect. Finally, they also pointed out that online resources were quite costly considering the overall costs of studying at a university, especially if one studied at a school away from his/her family and could not get much financial support. 


\section{Discussion and Conclusion}

Results In the present study on the second-year English language learners at the School of Foreign Languages (SFL) of Ankara Yıldırım Beyazıt University, an English-medium state university, we aimed to investigate the students' attitudes towards blended learning, as illustrated and experienced in the blended courses offered at the school, with reference to the six learning aspects identified by Tang and Chaw (2013) involving learning flexibility, online learning, study management, technology use, classroom learning, and online interaction, using the modified scale of Tang and Chaw (2013), over two academic years, 2016-17 and 2017-18. Additionally, a focus group interview was conducted with a group of 15 students to collect further qualitative data on their opinions and attitudes towards the blended learning aspects.

Overall, the findings from both data forms are in line with each other and shed a further light on the issues that should be taken into account while designating blended learning programs which integrate the modern ways of teaching via offering virtual learning environments, web-based platforms and mobile-assisted applications integrated into conventional learning settings. They are also considered from the perspective of change management (Kotter, 2012) in an effort to figure out the potentially successful ways to involve students more efficiently in the blended learning process as it requires a significant paradigm shift, by addressing the advantages as well as the potential drawbacks of the related blended aspects and thus benefit from this novel approach in more significant ways to enhance its sustainability.

The results in the current study indicated students with relatively higher language proficiency had a tendency to rate all the blended learning aspects quite highly, which points to possible links among such variables as language proficiency, learner autonomy and attitudes towards blended learning, and highlights how critical student characteristics and attitudes could prove in the implementation process. In this respect, such higher-achieving students in the AYBU-SFL context match the profile required in a blended learning environment where students take the responsibility of their own learning and become more independent learners enjoying the tech-induced options that allow more efficient personalized learning, self-reflection, participation, interaction, collaboration and help to overcome time- and placerelated constraints (Basal, 2015; Chapelle, 2010; Çelebi et al., 2016; Karatay, 2016; Korkmaz \& DemirBaşaran, 2016; Shannon-Chastain \& Fell-Kurban, 2016), and thus they hold positive attitudes towards and value such blended applications, as it has previously been observed in the related literature (Chapelle, 2009; Karatay, 2016; Tang and Chaw, 2013; Yelbay, 2011).

On the other hand, the combined data from both instruments revealed that students with limited or lower language proficiency, as reflected in their lower ratings and negative comments, reported to have suffered due to the limited in-class or face-to-face hours, having difficulty managing the flexibility in their schedules and achieving efficient personalized study in the absence of an authority figure or mentor or a better-equipped peer providing individual-specific attention and guidance, which relates to the Study Management and Online Learning aspects of blended learning. In fact, these two constructs received the lowest ratings from all the study participants in the AYBU-SFL context since, as defined previously, the blended learning program in this context primarily addresses students of a specific profile composed of low-achieving and unmotivated students who are not sufficiently autonomous in language learning to be able to cope with the proficiency exam preparation process by developing the essential study skills and strategies and avoiding procrastination and failure due to high levels of anxiety, low self-esteem and lack of motivation or awareness. Such findings are congruent with the previous research as well (e.g., Owston, York \& Murtha, 2013), which underlines the fact that self-disciplined and autonomous students can advance at their own learning pace and achieve their goals by enjoying their 
autonomy while low achievers pose a challenge in that they have difficulty adapting in the academic environment not knowing how to structure, time and manage their studies.

Despite the Study Management related challenges brought about in this blended learning environment evident in the lower ratings for the Study Management and Online Learning aspects, the high ratings for the Learning Flexibility construct in the questionnaire regardless of students' language proficiency levels and their positive comments as to this construct during the focus group discussion show that Learning Flexibility, as the most favorable blended learning aspect, serves students in significant ways providing a practical option for them to access the information anytime and anywhere via mobile technologies to perform authentic activities (Martin \& Ertzberger, 2013, Saran et al., 2012), gain time efficiency and location convenience (Brown, 2003; Singh, 2003; Tang \& Chaw, 2013) and adjust their path and progress at their own pace (Ja'ashan, 2015). Regardless, during the focus group discussion, some students associated their problems as to procrastination, lack of discipline or structure in their studies, time management issues, and cheating with the Learning Flexibility aspect as 7/24 available online resources and stress-free environment due to the absence of physical constraints are reported to have proved counter-productive from their perspective. Such lack of awareness with respect to the ways one can systematically exploit the materials made constantly available in a virtual learning environment again points back to the Study Management aspect and such students' immediate need for developing autonomous behavior through timely orientation, guidance and training, preparing them adequately for their new roles in a blended environment with $75 \%$ online content in the specific context of AYBU-SFL, as suggested in the related research (Dudeney \& Hockly, 2007; Harker \& Koutsantoni, 2005; Sagarra \& Zapata, 2008).

It is no surprise in this sense that as reflected in both their higher ratings on the attitude questionnaire and positive comments in the focus group discussion, students reported a need and desire for a higher number of face-to-face hours with their instructors and classmates, which relates to the Classroom Learning and Online Interaction aspects of blended learning. Contrary to what would be expected in a blended learning environment primarily relying on online content/interaction and limited in-class instruction, students held positive attitudes towards the Classroom Learning construct and preferred to meet with their lecturers and classmates in a classroom setting instead of on the web (Tang \& Chaw, 2013), although they did not report having experienced any difficulty using technology (the Technology aspect of blended learning). Nevertheless, interestingly enough, the underlying motive behind such desire turned out to be relating to the Study Management aspect again in that by abandoning the Online Interaction options such as Edmodo platforms and forums or outside-the-school study groups and getting more frequent face-to-face time, students believed they would build better rapport with their instructors and more disciplined classmates who would guide them during their learning process by reminding them of their goals and plans, helping them get motivated and organized, and checking on their progress, all pointing to their lack of autonomy or self-directed learning behavior.

Both sets of findings in this study as to the tricky boundaries among what is being blended, how it is being blended and how the proper functioning of the entire system can be achieved through the incorporation of additional elements are indeed indicative of important implications for the current practice at AYBU-SFL and the future blended learning applications in general. Wallace, Walker, Braseby, and Sweet (2014) define blended course instructors as cognitive coaches who design engaging learning experiences for students encouraging them to behave in autonomous ways; nonetheless, our findings, similar to the previous studies in the Turkish context (Basal, 2015; Çelebi et al., 2016; Karaaslan \& Çelebi, 2017) indicate that it is quite a challenge to free instructors and students from their traditional roles. Blended learning necessitates self-directed learning outside the classroom through discovery and experimenting, not necessarily under the guidance of a teacher; however, even highachievers have difficulty staying focused and keeping up with the coursework. Therefore, one 
implication of this study would be incorporating systematic training on autonomy-building and selfregulated learning into the overall blended education curriculum; and in fact, in response to this need to address learners' study management related expectations and assist them in their autonomy-building process, a Learning Advisory Program (LAP) was launched at AYBU-SFL in 2016, and the LAP became more of a service for the students after a group of nine instructors, in an effort to become learning advisors, received training from the experts in the field, affiliated with the Kanda University of International Studies in Tokyo, Japan, as part of the Project 3934, funded by AYBU Scientific Research Fund (BAP), as of November 2017.

Within the scope of the LAP program, students, who are largely unaware of their learning processes and language learning needs, are guided to gradually become aware of themselves as (language) learners in terms of their attitudes and behaviors as to getting motivated and finding joy in learning, challenging their existing values and switching viewpoints, setting goals, planning and organizing their time and study, taking action, selecting and using effective learning materials, strategies, and self-diagnostic tools, identifying their vision, keeping themselves focused and avoiding procrastination, recording progress, and reflecting deeply on the process (Kato \& Mynard, 2015). In order for a blended learning program to succeed and ensure its sustainability as part of effective change management efforts (Kotter, 2012), the instruction needs to be "personalized, serving individual needs; mastery-based, allowing students move on and receive credit only after they have mastered a core concept; and based on high expectations for all students and student ownership/agency, empowering students with the necessary skills, information, and tools to manage their own learning" (Karaaslan \& Çelebi, 2017, p.660), all of which could be attained with the effective incorporation of a learner training program, as in the example of the LAP at AYBU-SFL.

Some further adjustments could be made on the basis of student reflections regarding the blended learning program with respect to the online and/or in-class content as well as the costs involved. Students reported having used online resources without becoming aware of their potential benefits for their language development, just for the sake of completing their online assignments and getting the required scores, thus occasionally felt under stress in an effort to keep up with the coursework and subsequently developed a detest toward language learning altogether. They did not regard such resources as decent study and exam practice materials considering their costs; instead they preferred print test-books as they had a desire to accelerate their exam preparation process and believed the online content did not serve their purposes. There are two sides to such criticisms though, and they need to be handled with caution.

On the one hand, these relatively low-achieving students with limited autonomy are often unaware of their strengths and weaknesses as language learners, while on the other hand, they believe that even without a general English language background they can directly prepare for the proficiency exam which requires upper-intermediate level performance in all four skills including listening, reading, writing, and speaking, in the context of AYBU-SFL. This is partially due to their prior language learning experiences and long-established study habits consisting mainly of developing test-taking skills and strategies, discarding open-ended, process-oriented approaches to learning, due to the conditioning caused by the test-centered primary and secondary education systems in which the goal is entering prestigious schools taking multiple-choice exams administered at the national level in Turkey. Nevertheless, learning a foreign language is a long-term interactive process requiring continuity and development of competence in all four language skills in an integrated manner. Thus, adopting this perspective but still considering student expectations as to the content offered in blended learning contexts, blended program designers and instructors, as change agents helping students -one important group of stakeholders- to experience this perspective and paradigm shift, need to develop level-appropriate, cost-effective language learning materials including text assignments, games, recorded e-learning events, authentic materials, presentations, a wide range of testing and practice materials utilizing various delivery options in 
collaboration with publishing companies or funding bodies as totally online, self-paced, media rich, web-based materials may be too costly to produce (Singh, 2003). Such effort might help the change stick as students, believing their needs and expectations are being addressed in a collaborative environment, may develop stronger ownership of their language learning process and be encouraged to define their goals in more realistic ways, structure their learning more efficiently, and evaluate their learning outputs and gains, all of which contribute to their autonomy-building and self-regulated study behavior.

Overall, the current study points to some key considerations in any implementation that aims to blend learning. The course content should be carefully designed with a consideration of the specific student profile, their individual differences, and the costs involved. Further, students do not only need preparation and orientation prior to attending blended language courses regarding what the system consists and how it operates, but also constant and immediate feedback and support during the process regarding their progress as to language learning and autonomy building. As part of efforts to manage the change, secure its continuity, and involve, engage and enable the entire organization (Kotter, 2012), instructors and other staff also need similar orientation as to the functioning of the new system and their new roles.

Finally, this study was conducted at a single institution in one country but its findings are relevant to a wider audience receiving a variety of undergraduate blended courses. In addition, the results of the current study could guide all the parties involved in the decision-making processes of any teachinglearning setting including students, instructors, curriculum developers and course designers as well as the professionals and administrators in such institutions.

\section{Acknowledgements}

The blended learning program at AYBU-SFL was initiated and supported by Mümin Şen, AYBUSFL Director, and Müge Akdegik-Can, Asst. Director, and was designed and established by Hatice Karaaslan, Blended Learning Program Coordinator and Abdulkadir Güllü, IT Coordinator, Nurseven K1lıç and Gamze Güven-Yalçın, instructors in the core blended learning team. The authors would like to thank this extended team who wholeheartedly contributed to the entire process with their vision and research perspective, innovative ideas and constructive feedback.

\section{Authors' Note}

Preliminary findings of this study were presented at $13^{\text {th }}$ METU ELT Convention, 2018, Ankara, Turkey.

\section{References}

Basal, A. (2015). The implementation of a flipped classroom in foreign language teaching. Turkish Online Journal of Distance Education-TOJDE, 16(4), 28-27.

Beatty, K. (2010). Teaching and researching: Computer-assisted language learning (2nd ed.). Great Britain: Pearson Education Limited.

Brown, R. (2003). Blended learning: Rich experiences from a rich picture. Training and Development in Australia, 30(3), 14-17. 
Chapelle, C. A. (2001). Computer applications in second language acquisition. United Kingdom: Cambridge University Press.

Chapelle, C. A. (2009). The relationship between second language acquisition theory and computerassisted language learning. The Modern Language Journal, 93, 741-753.

Chapelle, C. A. (2010). The spread of computer-assisted language learning. Language Teaching, 43(01), 66-74. https://doi:10.1017/S0261444809005850

Creswell, J.W. (2012). Educational Research: Planning, Conducting and Evaluating Quantitative and Qualitative Research, 4th Ed. Upper Saddle River, NJ: Merrill.

Çelebi, H., Karaaslan, H., \&Demir-Vegter, S. (2016). Corpus use in enhancing lexico-grammatical awareness through flipped applications. Journal of Language and Linguistic Studies, 12(2), $152-$ 165.

Dudeney, G., \& Hockly, N. (2007). How to teach English with technology. Harlow: Pearson Education Limited.

Harker, M., \& Koutsantoni, D. (2005). Can it be as effective? Distance versus blended learning in a web-based EAP programme. ReCALL, 17(2), 197-216. doi:10.1017/S095834400500042X

Ja'ashan, M. M. N. H. (2015). Perceptions and Attitudes towards Blended Learning for English Courses: A Case Study of Students at University of Bisha. English Language Teaching, 8(9), 4050. https://doi.org/10.5539/elt.v8n9p40

Karaaslan, H., \& Çelebi, H. (2017). ELT teacher education flipped classroom: An analysis of task

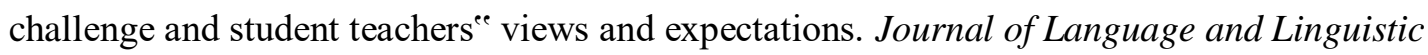
Studies, 13(2), 643-666.

Karatay, Y. (2016) An Investigation on Multimedia Language Laboratory in Turkish State Universities. İhsan Doğramacı Bilkent University, Graduate School of Education, Unpublished Master's Thesis.

Kato, S., \& Mynard, J. (2015). Reflective dialogue: Advising in language learning. New York, NY: Routledge.

Korkmaz,G. \& Demir-Başaran, S. (2016). Using Oxford iTools and iTutor Software in English Language Teaching and Its Effect on Preparatory Class Students' Academic Achievement. International Journal of Curriculum and Instructional Studies, 6(11), 55-69.

Kotter, J. P. (2012). Leading change. Boston, Mass: Harvard Business Review Press.

Levy M. (1997). CALL: context and conceptualization. Oxford: Oxford University Press.

Martin, F., \& Ertzberger, J. (2013). Here and now mobile learning: An experimental study on the use of mobile technology. Computers and Education, 68, 76-85. https://doi.org/10.1016/j.compedu.2013.04.021

Owston, R., York, D., \& Murtha, S. (2013). Student perceptions and achievement in a university blended learning strategic initiative. Internet and Higher Education, 18, 38-46. http://dx.doi.org/10.1016/j.iheduc.2012.12.003

Rahman, N. A. A., Hussein, N., \& Aluwi, A. H. (2015). Satisfaction on Blended Learning in a Public Higher Education Institution: What Factors Matter?, Procedia - Social and Behavioral Sciences, 211, 768-775. https://doi:10.1016/j.sbspro.2015.11.107 
Sagarra, N., \& Zapata, G. (2008). Blending classroom instruction with online homework: A study of student perceptions of computer-assisted L2 learning. ReCALL, 20(2), 208-224. https://doi:10.1017/S0958344008000621

Saran, M., Seferoğlu, G., and Çağıltay, K., (2012). Mobile Language Learning: Contribution of Multimedia Messages via Mobile Phones in Consolidating Vocabulary. The Asia-Pacific Education Researcher, 21, 181-190.

Shannon-Chastain, J. \& Fell-Kurban, C. (2016). Just one more hit: Student engagement with pre-class videos in the evolution of an English for Academic Purposes course from traditional to flipped. The Global e-Learning Journal, 5(2), 1-7.

Singh, H. (2003). Building Effective Blended Learning Programs. Educational Technology, 43(6), 5154. https://doi.org/10.1021/es2033229

Tang, C. M. \& Chaw, L.Y. (2013). Readiness for blended learning: Understanding attitude of university students. International Journal of Cyber Society and Education, 6(2), 79-100.

Wallace, M. L., Walker, J. D., Braseby, A. M., \& Sweet, M. S. (2014). "Now, what happens during class?" Using team-based learning to optimize the role of expertise within the flipped classroom. Journal on Excellence in College Teaching, 25(3\&4), 253-273.

Yelbay, Y. (2011). Yabancı Dilde Bilgisayar Yazılımı ile Sözcük Öğrenimi - Bir Model Denemesi. Ankara Üniversitesi, Sosyal Bilimler Enstitüsü. Yayınlanmamış Doktora Tezi.

\section{Appendix A. Sample blended B+ syllabus}

\section{ANKARA YILDIRIM BEYAZIT UNIVERSITY SCHOOL OF FOREIGN LANGUAGES GENERAL ENGLISH PROGRAM 2017-2018 PERIOD 2 \\ BLENDED B+ SYLLABUS}

\section{Course Materials \& Weekly Lesson Allocation: \\ Online (12 hours): $\quad$ NorthStar R\&W - L\&S 2-3 \\ In-Class (8 hours): $\quad$ Fundamentals of English Grammar (Azar) Workbook \\ Understanding and Using English Grammar (Azar) Workbook \\ Reader at Work 1 \\ Lecture Ready 1-2 \\ Writing \& Speaking Tasks}

Contact People:

Blended Learning Program Coordinator

Information Technology Coordinator

ILC Coordinator and LAP Unit

Main Instructors

\section{Evaluation Criteria:}

Online Assignments \& Online Tasks: $\quad 25 \%(15 \%+10 \%)$

NorthStar Vocabulary Quizzes: $\quad 10 \%$

Portfolio Tasks: $\quad 10 \%$

Midterm 1: $\quad 15 \%$

Midterm 2: $\quad 25 \%$

Quizzes (2): $\quad 15 \%$

Total: $100 \%$ 


\section{Weekly Plan}

\section{Week 1:}

Learning Outcomes:

By the end of this week, you will be able to:

- identify the main ideas in a reading

- identify different types of supporting details

- scan a text to locate specific information

- infer the author's opinion

- infer word meaning from context

- listen for main ideas

- listen for details

- recognize and use noun clauses (with that, if or whether, question words)

- recognize and use reported/quoted speech

- recognize and use verbs in reported/quoted speech

Workbook Assignments:

Fundamentals of English Grammar: Chapter 14: Noun Clauses

Reading Assignments:

Reader at Work 1: Texts 71-80

Listening Assignments:

Lecture Ready 1: Unit 4: Science; Chapter 8: The Influence of Geography on Culture

Vocabulary:

Lecture Ready 1:

Chapter 8: valley (n), location (n), isolated (adj), spread (v), exchange (n), barrier (n), inhibit (v), prevent (v), classic example (n), end up (v)

\section{Week 2:}

Learning Outcomes:

By the end of this week, you will be able to:

- make and confirm predictions (using a title and headings)

- identify the main ideas in a text

- identify different types of supporting details

- scan a text to locate specific information

- use inferences to make judgments about information in a text

- infer word meaning from context

- recognize and use adverbs of manner

- research and write about traditional ways of curing an illness (Online Task 1 Writing: Based on NorthStar Reading-Writing 2, Unit 7, pp.184)

- recognize phrases and intonation that express doubt

- analyze advantages and disadvantages

- give and respond to advice

- express opinions

- express concern

- use modals of advice and necessity (should, ought to, have to)

- prepare and present a smartphone application that will help people stay healthy (Online Task 2 Speaking: Based on NorthStar Listening-Speaking 2 Unit 7 pp.163-164)

- recognize and use the simple tenses (present and past)

- recognize and use the progressive tenses (present and past)

- recognize and use the perfect tenses 
- recognize and use the perfect progressive tenses

- read the text provided and write a response to it in a paragraph of 125 words (Portfolio Task 1)

- interview a classmate about his/her study habits and present a short oral report of it in class while at the same time giving advice if s/he has poor study habits (Portfolio Task 2)

Online Assignments:

NorthStar 2: Reading-Writing, Unit 7

NorthStar 2: Listening-Speaking, Unit 7

Online Tasks 1-2

Workbook Assignments:

Understanding and Using English Grammar: Chapter 1: Overview of Verb Tenses;

Chapter 2: Present and Past; Simple and Progressive

Reading Assignments:

Reader at Work 1: Texts 81-90

Listening Assignments:

Lecture Ready 1: Unit 5 Humanities; Chapter 9: The Story of Fairy Tales

Vocabulary:

North Star Level 2:

Reading-Writing, Unit 7: antibiotic, bandage, blood, cure, fever, flow, gently, patient, popular, relax, saliva, shot (n), sore throat, swelling, swollen, treat (v), vein

Listening-Speaking, Unit 7: connection, convinced, couch potato, criticize, enthusiasm, follow instructions, illness, motivate, motivation, needle, patient, physical, put a band aid on, simulation, support, traditional, treatment

\section{Lecture Ready 1:}

Chapter 9: magical (adj), creature (n), theme (n), character (n), protagonist (n), consequence (n), plot $(\mathrm{n})$, audience $(\mathrm{n})$, purpose $(\mathrm{n})$, assume $(\mathrm{v})$

\section{Week 3:}

Learning Outcomes:

By the end of this week, you will be able to:

- study a map

- understand the purpose of quoted speech in a text

- take notes from a text to support an opinion

- infer the author's attitude

- recognize and use be going to and will to make predictions

- write a paragraph to make a prediction about the survival of the Penan (Online Task 3 Writing: Based on NorthStar Reading-Writing 2 Unit 8 pp.208)

- recognize and use the perfect and perfect progressive tenses

- recognize and use modals of polite request (with I or you as the subject, or would you mind); necessity (must, have to); lack of necessity and prohibition (do not have to, must not); advisability (should, ought to, had better); obligation (be supposed to); unfulfilled intentions (was/were going to); suggestions (let's, why don't, shall I/we; could vs should)

- prepare a Kahoot vocabulary game based on the weekly vocabulary list (Portfolio Task 3) 


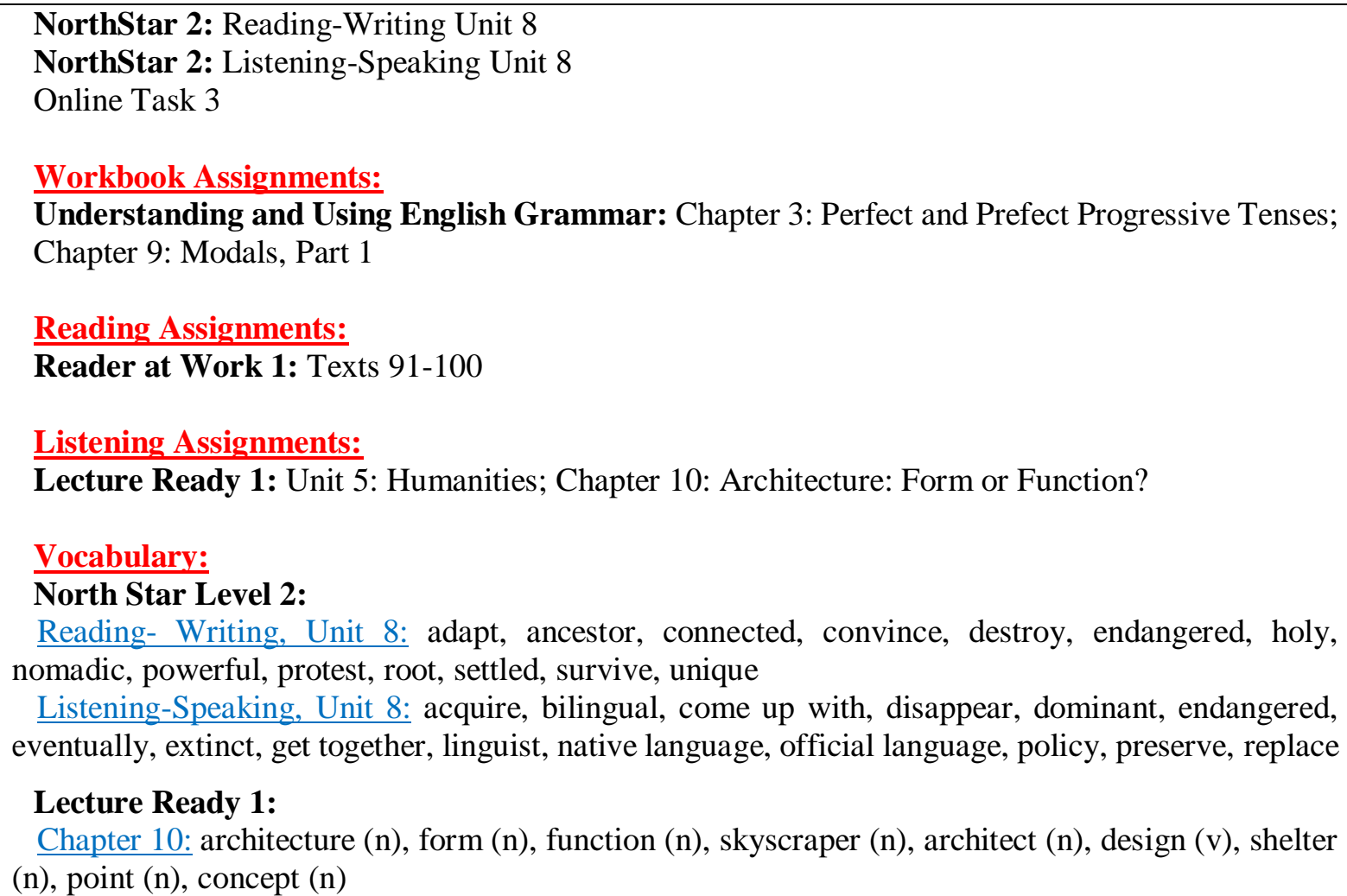

\section{Week 4:}

Learning Outcomes:

By the end of this week, you will be able to:

- make and confirm predictions

- identify the main ideas

- identify different types of supporting details

- scan a text to locate specific information

- recognize quotations and reported speech

- organize information using a Venn diagram

- infer the writer's degree of certainty

- infer word meaning from context

- recognize and use word forms

- recognize and use can, could, and be able to to express ability in the present, past, future, and present perfect

- recognize signal words that tell what to expect

- support ideas in one listening with examples from another listening

- express opinions about the quotes on motivation (Online Task 4 Speaking: Based on NorthStar Listening-Speaking 3 Unit 1 p.25)

- infer meaning from context in a listening

- recognize, use and distinguish between expressions with other (each other, another)

- describe goals and challenges

- recognize and use reflexive and reciprocal pronouns

- recognize and use will and be going to

- recognize and use the simple present and present progressive to express future time

- recognize and use the future progressive

- recognize and use the future perfect and future perfect progressive

- review verb tenses

- use knowledge of subject-verb agreement to form sentences (with expressions of quantity, there + be, and irregularities) 
- write a cause and effect paragraph of 150 words about one of the following topics: the reasons why people do sports, OR the effects of games on children (Portfolio Task 4)

Online Assignments:

NorthStar 3: Reading-Writing, Unit 1

NorthStar 3: Listening-Speaking, Unit 1

Online Task 4

Workbook Assignments:

Understanding and Using English Grammar: Chapter 4: Future Time; Chapter 5: Review of Verb Tenses; Chapter 6: Subject-Verb Agreement

$\underline{\text { Reading Assignments: }}$

Reader at Work 1: Texts 101-110

Listening Assignments:

Lecture Ready 2: Unit 1: Marketing; Chapter 1: Gender and Spending

Vocabulary:

North Star Level 3:

Reading-Writing, Unit 1: daring, inspire, focus on, impress, impressive, obsession, obsessive, willingness, unthinkable, complicate, complication, complicated, enormous, pressure, accomplish, accomplishment, accomplished, challenging

Listening-Speaking, Unit 1: marathon, course, format, stage, terrain, unique, tent, ration, get into, experience, goal, achieve, motivation, opponent, challenge

\section{Lecture Ready 2:}

Chapter 1: gender (n), market(n), consumer (n), study (n), innovative (adj), strategy (n), appeal (v), implication (n); to have a say

\section{Week 5:}

Learning Outcomes:

By the end of this week, you will be able to:

- scan a text to understand chronology

- identify detailed examples

- infer comparisons

- recognize and understand synonyms

- recognize and use word forms

- recognize rhetorical questions

- infer a speaker's feelings from intonation and stress

- interpret positive and negative connotations of words

- recognize and use nouns (singular/plural, count/noncount, possessive, with expressions of quantity-a few, few, a little, little; one, each, every; of ) and articles

- recognize and use pronouns (personal/reflexive/indefinite; generic, collective, impersonal (you, one, they); forms of other; common expressions with other)

- recognize and use the passive (all forms)

- use pictures that tell a story or message (Google for pictures with a story or message) and talk about the message/story behind for about 2 minutes (Portfolio Task 5)

Online Assignments:

NorthStar 3: Reading-Writing, Unit 2

NorthStar 3: Listening-Speaking, Unit 2

Workbook Assignments: 
Understanding and Using English Grammar: Chapter 7: Nouns; Chapter 8: Pronouns; Chapter 11: The Passive

Reading Assignments:

Reader at Work 1: Texts 111-120

Listening Assignments:

Lecture Ready 2: Unit 1: Marketing; Chapter 2: Ads are Everywhere

\section{Vocabulary}

\section{North Star Level 3:}

Reading-Writing, Unit 2: fraud, fraudulent, motive, impersonate, impersonating, deceive, deception, suspicious, fake (n, adj), honesty, fishy, astonishing, duplicate (v, adj), weary

Listening-Speaking, Unit 2: confirm, charge, purchase, authorize, file a complaint, victim, expose, exposed, paranoid, proof of identification, deal with, commit, protect, risk, tip, shred

\section{Lecture Ready 2:}

Chapter 2: product (n), logo (n), brand name (n), perspective (n), promote (a product) (v), costeffective (ad) (adj), high-tech (company) (adj); in the long run

\section{Week 6:}

\section{Learning Outcomes:}

By the end of this week, you will be able to:

- analyze problems and solutions

- evaluate pros and cons

- organize ideas in an outline

- write a paragraph about the pros and cons of building a colony on Mars (Online Task 5 Writing: Based on NorthStar Reading-Writing 3 Unit 3 pp.66-71)

- understand inferred meaning (degrees of difficulty) in a text

- use knowledge of academic vocabulary to formulate collocations

- recognize and express purpose with an infinitive after verbs or after a verb and in order to

- distinguish between similar sounding numbers

- determine pronoun references

- infer factual information from context

- recognize and use modals of certainty (present, past, future); ability (can/could); preference (would rather); with phrasal modals; progressive forms of modals

- revise noun clauses (subject and object position)

- recognize the parts of an opinion essay (introduction, body, and conclusion) (based on extra material)

- write a thesis statement and prepare an outline for an essay

- ask and answer questions based on the prompt cards provided (Portfolio Task 6)

Online Assignments:

NorthStar 3: Reading-Writing, Unit 3

NorthStar 3: Listening-Speaking, Unit 3

Online Task 5

Workbook Assignments:

Understanding and Using English Grammar: Chapter 10: Modals, Part 2; Chapter 12: Noun Clauses

\section{Reading Assignments:}




\section{Listening Assignments:}

Lecture Ready 2: Unit 2: Social Sciences; Chapter 3: Work Habits in the United States

\section{Vocabulary:}

\section{North Star Level 3:}

Reading-Writing, Unit 3: artificial, automatically, boredom, count on, depression, engine, establish, isolated, reaction, research (n.), simulate, speculation, spin, survive

Listening-Speaking, Unit 3: collide, cooperate, crew, damage, debris, fragment, innovation, orbit, particle, perspective, precious, promote, satellite, spacecraft, track

\section{Lecture Ready 2:}

Chapter 3: analyze (v), trend (n), juggle (v), role (n), efficient (adj), pressure (n), workplace (n), value (n); it turns out that;

Common symbols used during note-taking:

\begin{tabular}{|c|c|c|c|}
\hline$=$ & equals, is the same & $\#$ & number \\
\hline$\neq$ & is not the same & wl & with \\
\hline$>$ & is more than & w/out & without \\
\hline$<$ & is less than & + & and \\
\hline$\sigma$ & man & $\downarrow$ & to go down, decrease, lower \\
\hline \& & woman & $\uparrow$ & to go up, increase, higher \\
\hline$\triangle$ & changing & $!$ & (to mark importance) \\
\hline
\end{tabular}

\section{Week 7:}

\section{Learning Outcomes:}

By the end of this week, you will be able to:

- recognize opinions and supporting examples

- organize ideas using a chart

- infer the meanings of proverbs

- recognize and understand antonyms

- recognize and use word forms (nouns, verbs, adjectives, and adverbs)

- recognize and make comparisons with adverbs

- recognize intensifiers that emphasize ideas

- find advertisements for the same type of product (e.g. cars) from two different companies and analyze them (Online Task 8 Speaking: Based on NorthStar ListeningSpeaking 3 Unit 4 p.102)

- infer a speaker's purpose

- recognize and use intonation and stress for emphasis

- categorize common words and phrases in advertisements

- recognize and use superlative adjectives

- recognize and use adjective clauses

- recognize and use conditional clauses and wishes

- write a well-organized opinion essay of 200 words about: "Do you think social networking sites (such as Facebook) have had a huge negative impact on both individuals and society?" (Portfolio Task 7)

Online Assignments:

NorthStar 3: Reading-Writing, Unit 4

NorthStar 3: Listening-Speaking, Unit 4

Online Task 6

\section{Workbook Assignments:}


Understanding and Using English Grammar: Chapter 13: Adjective Clauses; Chapter 20: Conditional Sentences and Wishes

Reading Assignments:

Reader at Work 1: Texts 131-140

Listening Assignments:

Lecture Ready 2: Unit 2: Social Sciences; Chapter 4: Leisure Time in the United States

Vocabulary

\section{North Star Level 3:}

Reading-Writing, Unit 4: assertive, dialect, dominate, exception, excessive, inferior, myth, profanity, proverb, sexism, slang, synonym, talkative, uniqueness, valued (adj.)

Listening-Speaking, Unit 4: compact, connotation, context, corporate, cozy, deceptive, directly, euphemism, excessive, fire, maintenance, reduction, transition, vibrant, vintage

\section{Lecture Ready 2:}

Chapter 4: survey (n), pace (n), relaxation (n), stressed-out (adj), multitasking (n), exhausting (adj), no-brainer (adj), hang out (phv)

Common abbreviations:

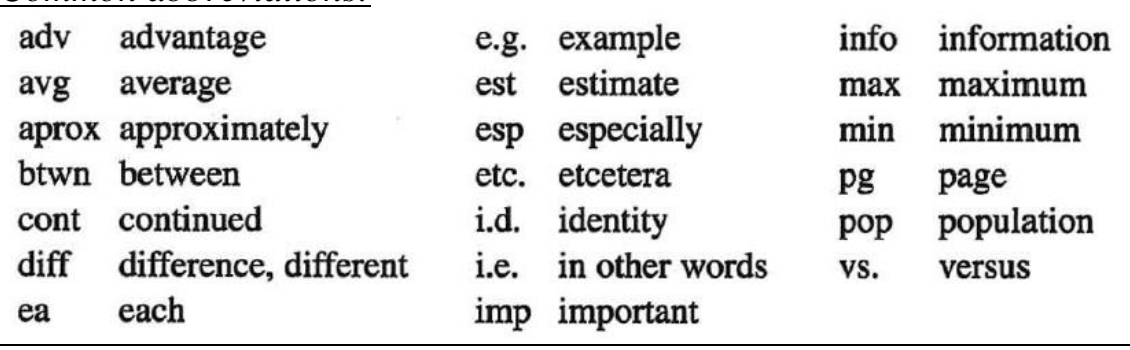

\section{Week 8:}

Learning Outcomes:

By the end of this week, you will be able to:

- revise all the items in the lexical and linguistic range specified

Reading Assignments:

Reader at Work 1: Texts 141-150

Listening Assignments:

Lecture Ready 2: Unit 3: Science; Chapter 5: Science of Pleasure: Choosing What We Eat

Vocabulary:

Lecture Ready 2:

Chapter 5: diet (n), recommendation (n), nutrition (n), source (n), influence (v), controversy (n), debate (n), pleasure (n), give up (phv) 


\section{Öğrencilerin karma dil derslerine yönelik tutumları: Bir durum çalışması}

\section{$\ddot{\mathbf{O z}}$}

Zenginleştirilmiş dil öğrenme ortamları oluşturmak amacıyla dil öğretmenleri, ders ve program geliştirenler ve yayın şirketleri uzun bir zamandır yeni ve alternatif fikirler geliştirmek için çalışmaktadırlar. Bu nedenle; sanal öğrenme ortamları, web temelli platformlar ve mobil destekli uygulamalar şeklinde ortaya çıkan bilgi ve iletişim teknolojileri bu alanda önemli bir yer edinmiştir. Sınıf dışında öğrenim olanağı sağlayan yeni araç ve platformların ortaya çıkmasıyla birlikte, öğrenme sürecinde öğrencinin kendi öğrenme süreci üzerinde takibine de olanak sağlayan, elektronik öğrenme ve geleneksel öğretim metotlarını harmanlayan karma öğrenme yöntemi gelecek vadeden bir seçenek olarak popülarite kazanmıştır. Bir Yabancı Diller Yüksekokulu bünyesinde ikinci senesinde programı tekrar eden öğrenciler üzerinde gerçekleştirilen bu çalışmadaki temel amaç Tang ve Chaw'ın (2013) öğrenme esnekliği, çevrimiçi öğrenme, çalışma yönetimi, teknoloji kullanımı, sınıf içi öğrenme ve çevrimiçi etkileşim olarak tanımladığı altı öğrenme bağlamındaki karma öğrenme yöntemine yönelik öğrenci tutumlarını incelemektir. Öğrencilerin uygulanan ölçeklere vermiş oldukları cevapları betimleyici istatistiklere ve ölçeğin alt boyutları arasındaki iç tutarlılık testlerine tabi tutulmuştur. Çalışmanın nitel verilerinin elde edilmesinde ise 15 öğrenciyle gerçekleştirilen odak grup görüşmesinde öğrenciler karma öğrenme yöntemine yönelik düşünce ve tutumlarını deneyim ve beklentilerinden hareketle ifade etmişlerdir. Dil yeterliği yüksek olan öğrencilerin karma öğrenmeye yönelik tutumlarının olumlu olduğu, ancak dil yeterliği nispeten sınırlı olan öğrencilerin ise daha çok yüz yüze ders yapma ve etkileşim içinde olma, ders çalışma sürecini yönetme noktasında destek alma ihtiyaçları içinde olduğu yönündeki bulgular öğrenci dil yeterliği, otonomi ve karma öğrenmeye yönelik tutum arasında olası ilişkilere işaret etmektedir ve bu yöntemle yapılan uygulamalarda öğrenci özelliklerinin ve tutumlarının ne oranda etkili olabileceğini vurgulamaktadır.

Anahtar sözcükler: Karma öğrenme; öğrenci tutumları; otonomi; dil yeterliği; öğrenme uyumu

\section{AUTHOR BIODATA}

Hatice Karaaslan is a language instructor at Ankara Yıldırım Beyazıt University, with a PhD in Cognitive Science from METU. Her interests include corpus linguistics, argumentation and critical thinking, advising in language learning and blended learning. [hkaraaslan@ybu.edu.tr]

Nurseven Kılıç currently works as an instructor of English language at Ankara Yıldırım Beyazıt University. She is a Ph.D candidate in the field of Guidance and Psychological Counseling at Eskişehir Osmangazi University. Her interests include self-construals, moral development, narcissism, schema theory, motivation, well-being, anxiety, life satisfaction, happiness, and blended learning. [nkilic@ybu.edu.tr] 